\title{
Subtitling as a Didactic Tool for Relating Exactness of Information and Cultural Preservation: The Igbo Language Mediascape Example
}

\author{
Christopher Chinedu Nwike \\ Department of Linguistics, Igbo and Other Nigerian Languages, University of Nigeria, Nsukka, Nigeria \\ Olaide Oladimeji \\ Department of Linguistics and Languages, Federal University, Oye-Ekiti, Ekiti State, Nigeria \\ Obiora Harriet Chinyere \\ Department of Linguistics, Igbo and Other Nigerian Languages, University of Nigeria, Nsukka, Nigeria
}

\begin{abstract}
Translation is a language activity that involves intercultural activities. The study's focus is on subtitling as a didactic tool for relating exactness of information and cultural preservation: The Igbo language Mediascape example, by looking at the correctness of the subtitled expressions in context, in the movie used for the study. Language is a human form of communication in his sociocultural environment as well as culture which is people's way of life. The study adopted the frameworks of Gotlieb's strategy and Nida's equivalence to tackle the study's problems. It also adopted the methodology of description and emergent design approach in the study. For the correctness of the source information expressions in context, it is discovered that by the use of Gotlieb's strategy and Nida's translation equivalence, the study was able to transfer right messages in the context in which they are used. It is discovered that the research objective of the study is achieved thereby attaining the signification of the study.
\end{abstract}

Index Terms-language, culture, context, translation and subtitle

\section{INTRODUCTION}

Translation is an exercise that involves cultural documentation and cross fertilization of different cultures of the world hence, playing active and important roles of crossing through different cultures and communication. This cultural documentation in the context of translational exercise is what Nord (1997) sees as a process of linguistics and cultural adaptation to the original information. Based on this ground, the idea of translation and its relationships are not to be misunderstood thus; a free translation is that type of rendering of the original information into the target and still retain s the taste of the source text with the culture and language of the target audience. In this study, it will be taken to be that translation that is free in the sense that there is always a clear connection or relationship between the original information, culture and source audience, hence, the value of the sort is still extended to the relationship that exist between the information, culture and target audience. However, for Fawcett (1996) this kind of translation that involves cultural acceptance by the target audience during the information transfer can said to be sociolinguistic based because, its involvement revolves around how the different translators who engages in cultural related form of translation can adapt the source text in the target language and culture, acceptable by the target audience. This is to say that translation is an essential, fundamental and adequate way of interchanging cultures. In doing this, Munday (2001) believes that the process will involve adapting the lexicon, grammar and cultural references of the target language in order to attain naturalness in the translated information.

In connection with the above information, translation is not an action that exists in isolation rather, use of language and other forms of techniques that is known by the translator. Upon this, language, it is a form of human expression that is very important to mankind in his sociocultural environment. According to Gelavizh, Saman, Elenaz, Arezoo and Siamak (2012), languages phenomenon and factors links different cultures of the world, including the ways feelings are expressed and conveyance of people's thoughts and ideas. The thought of translation in this study is not limited to only textual form of translation rather, paratextual. It is called paratextual form of translation in the sense that it involves a non book transfer of information. This non book transfer is what this study sets to call a media translation or audiovisual translation (AVT) wherein, it is divided into two thus; dubbing and subtitle. Audiovisual translation (AVT) is what Szarkowska and Wasylczyk (2018) believes to be how films and TV programmes are translated from one language to another viz dubbing or subtitling. Dwyer (2017) added that subtitling and dubbing are subfields under translation. So, 
from the two subdivisions of the media translation or audiovisual translation, the focus of the study dwells on subtitle alone. Based on the sense that the subtitle is used in this study, it is taken to be the substitution of the spoken utterances of a particular movie device with its written equivalence on the screen. Subtitle is an exercise different media houses of the world are using in relating particular information to a particular target audience. In the process of transferring this information, it can be discovered that there are lots of subtitled movies with wrong expressions in terms of grammar and context, poor punctuation, capitalization, non alignment with the spoken and the written utterances on the screen - the African Magic Igbo movie example. Based on all these problems discovered of the media houses that adopt subtitle, this study sets to use these problems as the studies problem of the study.

In connection with the above information, in looking at subtitle in this study, the exercise shall dwell only on the selected Igbo movie of the Nollywood industry while the Igbo movie that will be used for the study is called Aka azu di $y a$. In studying this movie of the Nollywood industry, the scope that this study sets to cover is only on 'the correctness of the subtitled expressions in context' in order to get down the information to the target audience. However, the movie is in Igbo language and as such, English language is the language that was used to adapt the Igbo movie and culture into another culture. In line with this, in order to make sure that there are no meaning losses in the transferred information, the researcher, through this exercise will help make sure that the original information is retained functionally in the target language through ensuring that the correctness of the subtitled expressions of Aka azu di ya is rightly rendered grammar and context based. In this study, the grammar is taken to be the internalized knowledge the owners or speakers of a particular language have about the inherent different units and rules of their language that touches the rules used for combination of speech sounds into word formation, making sentences and assigning meaning to words, sentences and phrases. This is to say that when a sentence is discovered ungrammatical in a linguistic sense, it implies that the sentence construction has broken the rules of the shared mental grammar of the language which will definitely affect the exactness of the meaning of the intended information.

\section{A. Language}

Due to the level of the importance of human communication in his sociocultural environment, it is very pertinent to state the relevance of language with culture and translation as valuable issues. Upon this, due to the many languages of the world with different cultures that allows communications in the human life, it then make the process of transferring information to be a very effective factor in information exchange, transferring cultures, belief systems, knowledge and ideas. This is to categorically say that language and culture are much related and as such, very crucial to be taken into consideration during any form of translation exercise. According to Gelavizh, Saman, Elenaz, Arezoo and Siamak (2012), language is an exercise that is used to maintain and convey culture as well as cultural ties. In different human environments, people communicate with each other and as such, opinions, knowledge, beliefs, wishes, threats, commands, thanks, promises, declarations and feelings are exchanged. However, one can carry out this communication form as one can frown to express hatred, joy or happiness. Again, one can smile to show that he or she is happy as well the act of approving of something. It can also be use in the situations of hard feelings; one can actually shriek face in order to express anger. More so, based on this communication role of language, one can clench his or her fists to express determination, anger or a threat as well as raise his or her eyebrows to express surprise or disapproval language. In line with the following, in this study, any form of communication by means of language may be referred to as linguistic communication while the other forms outlined earlier, thus laughing, smiling and shrieking are called nonlinguistic communication.

Based on the above, Gelavizh, Saman, Elenaz, Arezoo and Siamak (2012) state that ideas are borne out from the differing language use in one's culture which its relationship start at one's birth. Due to the fact that language exist only with men and no other form of being or animal, it can on that ground be called a human capacity that acquires and uses different complex systems of communication in mans sociocultural group. This is to clearly say that the part of the human brains that works on language is basically greater than that of other forms of species in an ecosystem because; language in its entirety is rule based. So, based on the relationship that exist between translation, culture and language, it can be seen that languages and culture are complimentary of each other in the sense that the cultural features of every region is different and as such, one who translates the original information will be able to render exactly the meaning of the ST and at the same time strike a balance by showing the discrepancy between the culture of the ST and TT.

\section{B. Concept of Culture}

Culture can be seen as the way a group of people sees life. For Newmark (1988), culture is defined as the way a group of people live their lives in a way that is very good to them, although shares semblance in language as it is used for communication. However, this implies that language is not regarded as a component or feature of culture which is in direct opposition to Vermeer (1998) propositions of language being part of a culture. For Gelavizh, Saman, Elenaz, Arezoo and Siamak (2012), culture means the designed life pattern and belief system of a group which in other words will extend to the form of child rearing practices. In relation to the previous propositions, it can be said that culture is the general way of living that is designed to govern a group of people that is generational in its essence because it is touches belief system, art, morals, law and customs. According to Parson (1949), culture is taken to be the integral part of every society of the world in the sense that it can be seen as a learned way of behaviour as well as the style in which one lives his or her life. In every sociocultural group, it is very important to state that culture is very pertinent for the 
existence of a society, since it binds a group of people together. Explicitly, the term culture encapsulates or embodies the music, food, arts and literature of a society.

In consonance with the above discourses, it can be seen that a group of people have a form of life and beliefs acceptance towards the way they live their lives. In speaking with the same language, it can be said that it is because of an effective communication which could be in form of linguistic or non-linguistic form of communication. Categorically, Newmark (1988) believes that translation involves effective understanding towards the source text in order to communicate well the original information in the target text since the transferring of the ST information is done through having its equivalent target language text. For Gelavizh, Saman, Elenaz, Arezoo and Siamak (2012), translation involves language and culture. Based on the following discourse, it can be said that there are two important things that will take place before there will be a good translation (Larson 1998). Upon this, they are adequate understanding of the source text and culture as well as adequate command of the language into target language and culture. Based on the foregoing, Larson (1998) postulates that translation is a process that is complicated; being complicated in the sense that any translator who is involved in any form of meaning transfer will definitely find out that there are norms and values in what that is involved in the target language. However, the target language has a way in which the desired meaning is expressed, not considering the form of the textual materials of the original information but the content. This is because, the act of transferring information from one language to the other is no longer seen as an ordinary cross-linguistic activity, rather, a significantly form of cross-cultural communication. So, in order to maintain a peaceful atmosphere in the human's communities, Gelavizh, Saman, Elenaz, Arezoo and Siamak (2012) postulate that there is a form of culture that is seen universal that enhances communication as well as change of ideas in order to achieve progress in all life domains. However, in the spiritual and material life of the human race, concentration of mutual efforts in different directions, change of ideas and communication among different peoples in different ways are very important. On the contrast, there can be discontinuity of cultural acts at certain times, in the sense that the breach of cultural act is based on the existence of models and not to a state of nothingness. So, within the human regions, cultures are transferred through the languages by the strong relationship between culture and language that gets manifested through translation. So, upon this, this translation accentuates the process and the possibility of transferring sense and meaning from one language to the other by means of the word made manifest through translation.

\section{THEORETICAL FRAMEWORK}

Translation as used in the study involves information transfer. The different entertainment industries of the world have used this process to relate much information to people. The focus of this study is on media study of the Nigerian Igbo Nollywood movie. According to Giwa (2014), the Nollywood is a film industry that is owned by Nigeria to oversee the entertainment activities in Nigeria that involves music, songs and drama which equally extends to cinema. Translation, according to Schaffner (2007), is involved with bringing across information from one language to another language. However, this process makes the translational exercise to be involved with the movement from one position to another. So, the language that owns the source information is the source language (SL) while the language that is used to receive the ST into the TT is the target language (TL). Additionally, the TL can as well be called the receiving language since it is the language with which translation is done. On the other hand, Bassnett (2008) sees translation as a form of meaning transfer that that enables the message of the original text to be the same with the rendered information, such that one who reads the two works will perceive same sense of meaning, thereby making the structures of the SL to be well preserved as closely as possible but not so closely that the TL will not be understood. During rendition exercises, the translator understands perfectly well the content and the intention of the author whom he is translating his work, and this is done by reading all the sentences or the text properly, and have a firm grasp of the source text information in order to translate properly, since translation focused on clarity of meaning and meaning retention. In line with this, Hatim and Mason (1990) state that translation is a process that is involved with negotiation of meaning between producers and receivers of the text. For Jiraphatralikhit, Kaewjan, Klinpoon, Visitwanit (2005), translation enhances the reproduction of meaning that is natural or approximately similar to the target language in content and form. However, if translation is involved with information transfer, it can then be said that it has a big role to play. So, the act of proper cross fertilization of ideas and cultures is being done effectively through translation in the period where the interactions among disciplines are involved. This is to say that those who engage in translation activities helps to break down or decodes information from language A to language B so that those who lack mastery in the source language will be able to understand a text written in a language different from their own (Nwike, 2021). However, the focus of the study is on a literary form of translation where the study is 'subtitling as a didactic tool for relating exactness of information and cultural preservation: The Igbo language mediascape example'. This is to say that in looking at subtitle as a didactic tool for relating exactness of information and cultural preservation: The Igbo language mediascape example, the study then adopts the movie titled - Aka azu di ya, a dramatic translation that shares semblance with literary elements like literary textual translation. In preserving culture of a particular language, the translator makes sure that the right principles are adopted in other to have faithful translation and translational acceptance by the target audience.

In line with the above discourses, Newmark (1991) came up with the working connection between semantic and communicative translation. For him, translation should be more or less semantic as well as more or less communicative. However, according to him, a particular part or sentence can be treated in a more communicative way or less 
semantically. This is to say that both approaches seek for an equivalent effect. On the other hand, strategies are applied on cultural translations in order to faithfully produce the original information of the source language in the target language. These strategies are for translating culture-specific concepts (CSCs). According to Graedler (2000), they are to:

i. Make up new words.

ii. Explain the meaning of the SL expression through translation.

iii. Preserve the SL term.

iv. Used of words in the TL which seems similar to or has the same relevance in TT as the SL term.

From the above outlines, Harvey (2000) states that in explaining the culture-bound terms (CBTs) like institutions and personnel, which are specific to the source language culture that there are approaches to them. However, Harvey put forth four techniques for translating culture-bound terms, and they are as follows:

i. Functional Equivalence: This type of equivalence is involved with replacement of the SL information with that which is similar to that of the source language referent and this is the reason why Weston (1991) says that functional equivalence is the ideal method of translation.

ii. Descriptive Translation: This form of translation involves the definition of the SL terms with the TL terms and phrases in order to avoid meaning loses and ambiguity of words during translation. This is a method that is seen to be appropriate in situation where there is lack of replacement of the SL information in a formal equivalence form of translation. So, for the information that is aimed at specialized readers, this method can assist in adding the original source langue term to avoid ambiguity (Harvey, 2000).

iii. Transcription: This can be called transliterating the original term. It stands at the far end of source language oriented strategies. This is to say that in a situation where terms and phrases are explained in context, transcription can definitely be used especially where there is lack on the knowledge of the source language on the part of the target audience. Categorically, transcription is substituted with an explanation or a translator's note.

iv. Formal Equivalence: Translation of this kind means a word-for-word translation (Harvey 2000).

Based on the different realizations on how well to go about having a good translation, Nida (1964) came up with the idea of dynamic equivalence. This form of information transfer is based on the rendition that enables the original information to be transferred sense for sense from language A to language B in the sense that the original meaning of the Language A information is maintained in the language B with dropping or meaning loses. According to Nida (1964), the step that is involved in this type of translation is involved with taking each term, sentences or phrases thought from the ST and transposes it in a form that is same with the original piece in the TL text. The idea behind this dynamic equivalence is to improve readability by rephrasing constructions that could be confusing when literally translated. This is to say that the process that is involved in the dynamic equivalence tries to retain some originality of the source information in the target than creating a complete paraphrase. Again, in achieving a more natural translation, the dynamic equivalence sacrifices faithfulness to the original text since it is formed in order to be used when priority is on the content and not the form. A dynamic equivalence is useful when the original language is very different from the target language because, it helps in understanding better the literal translation.

\section{A. Concept of Subtitle}

Based on the above discourses, Gottlieb (1992) sees subtitle as a written, additive, immediate, synchronous and polymedia translation. In line with this, one can say that the subtitle is a subordinate translation that has a restriction of time and space which directly affect the final result on the screen towards the information transfer. However, subtitle is not just an embodiment of relating information of the original to the target audience, rather, it support viewers in the image and the audio with determined time and space on the screen. Upon this, the work of Fawcett (1996) postulates that this audiovisual translation has gained momentum in the scope of translation studies due to the role it plays in relating information, possibly, to the foreign language learner of Igbo language or one who suffer hard of hearing as well as one who is hearing impaired. On the part of Shuttleworth and Cowie (2007), subtitle and dubbing is one of the two modes of audiovisual translation that can be seen as terminologies that are used for transfer in media pieces. On this, subtitle can be called condensed written information of the spoken utterances of the actors on the screen which is written on the foot of the screen. In line with this, subtitles are set to appear and disappear to match in time with the corresponding portion of the original dialogue. In other words, it is always added to the screen image at a later date as a post-production activity. According to O'Connell (2007), they are cinema, television, video, DVD, LaserDisc, CDRom, computer games, Internet and live performances. On the contrast, it receives more benefits over dubbing because; it is foreignculture friendly, quick, inexpensive and a bit politically correct mode of screen translation. Again, on the systematic basis, subtitling stands as a challenge to the traditional or cultural translation because of space and not much time involved in the visual conventions as well as the possible shift of the methodologies from spoken to written information in the process. Upon this, challenges are not categorically hinged on the multitude of the types of subtitling but on the fact that it has a lot to do with technology and not only with language.

\section{B. Classification of Subtitling}

On the basis of subtitling classification, Gottlieb (1992) is of the view that subtitle can be divided into intra-lingual and inter-lingual subtitling on the basis of linguistic. Upon this highlight, the intra-lingual subtitle can be referred as the 
production of subtitles that remain in the same language as the original. So, on the act of rendering the words of the source information to another language, the intra-lingual subtitling aims at changing the mode of speaking and not the language itself - dialect variety of Igbo language to standard Igbo orthography. In line with this, it is discovered that it is obvious that the class of people that use it most often are the people who are deaf or have hearing impairment, or for language learners, except on special cases where it is strictly for fun. On the other hand, an interlingual subtitle is the change on both the language mode, where the original sound is retained from ST the TL thus, through spoken dialogue to its written equivalence on the screen - standard Igbo to Yoruba language. Sequel to the classification of subtitle, Gottlieb (1992) maintains that those who engage in subtitling transposes the spoken utterances of a media piece through writing on the screen so that those who suffer hard of hearing or are hearing impaired as well as foreign language learners will be able to have a firm grasp of the original information of the actors on the screen.

In alignment with the information above, Liu (2014) postulates that there are some other approaches to the guiding principles of classification in subtitle study. So, upon this classification of subtitle, Ivarsson (1992) proposes a subtitle classification in which linguistic and technical parameters as well as other parameters are involved. The classifications are based on the areas of application, audience, writing skills and time. In line with these parameters, there are six types of subtitle. According to Liu (2014), they are subtitle for cinema and television, multilingual subtitle, teletext subtitle, reduced subtitle, subtitling live or in real time; although, one can say that there are theatrical works and conference subtitles. In line with the following, there are characteristics of subtitling according to Liu (2014).

i. Time and Space restrictions: The major feature or characteristic of subtitle is not much time and space on the screen which determines and affects the standard and forms of rendition (Liu, 2014). However, during subtitling, the spacing is to be limited to two lines at the bottom of the screen of the television or cinema without interfering with the image. In doing this, it is expected that no line on the screen will contain more than 35 characters. Again, a minimum period of a second and maximum duration of six seconds is the limits of time on the screen in order to enable the viewers to quickly read and comprehend the presented message. So, in the subtitling process, those who are involved with the exercise should try as much as possible to align properly the image and the audio.

ii. Instantaneity: The focus herein is being immediate with the presentation of the written information on the screen alongside with its spoken utterances. According to Gottlieb (1992), subtitling is an instant form of rendition as it combines with an image that helps the viewers to comprehend the media piece.

iii. Colloquialism. Subtitles in this sense suggests that the process should be real in the sense that it will be lifeoriented with eye-catching with some simple expressions on the screen as movies pursue the authenticity of life schema and not just life inspired literature (Liu, 2014).

On the contrast with the exactness and intricateness of the above Liu (2014) information, Bartoll (2004) differentiated his types of subtitle based on meticulous parameters. Upon this, there are nine parameters of subtitling and they are placing, the filing of subtitles, localization, mobility, optionality, time, audiovisual product to be subtitled, channel/means of broadcast and colour (Bartoll, 2004). For him, placing involves centered and non-centered subtitles while filing involves inseparable and separable parts like electronic subtitles. Another is localization and on this, it involves intertitles and surtitles. More so, mobility connotes mobile and fixed subtitles while other prosody is optionality while involves optional or closed subtitles and non-optional or open subtitles. Again, time is involved with pre-recorded and simultaneous subtitles while the other classification is audiovisual product to be subtitled. Herein, it involves cinema, television, video, DVD, LaserDisc, CDRom, computer games, Internet (Streaming Video), and live performances. For channel/means of broadcast, it involves the audiovisual product itself through electronic teletext display that is projected on top of the product. More so, colour is another classification that depends on the interlocutors. However, the colour of the film whether in black and white or coloured is used on the products to be subtitled.

Based on the above information concerning the classifications of Liu (2014) and Bartoll (2004), the two approaches exhibit the same drawback which implies that the both tries to take all, although, by the of the process, they turn out to overlap and become applicable. Irrespective of the principles, there are two distinctions of subtitle which are the traditional classification and the new classification. Under the traditional classification, there are two forms of classifying subtitles on the basis of two different parameters. The parameters are linguistic and technical.

\section{Subtitle Strategy}

In order to have a good transfer worthy of acceptance by the target audience in a particular movie device, it is good to consider all the factors that necessitate it. On this, according to Gottlieb (1992), there are strategies of subtitle and they are:

i. Expansion: This is used for the source information when it requires explication due to gaps in the involved cultures.

ii. Paraphrase: This involves reconstruction in the same syntactic way in the target language, especially where the phraseology of the original is not same in the target language.

iii. Transfer: The idea in this strategy is involved with rendering the ST same in the TT.

iv. Imitation: This form of strategy retains exactness of the forms in the ST into the TT.

v. Transcription: This strategy is used to give clarity to a source language terms and phrases that are unusual even in the source text but needed to have a semblance of the information in the target language. 
vi. Dislocation: This can be called a step the source text information adopts in a case where it involves some kind of special effect.

vii. Condensation: The adoption of this method results to shortening of the source information in a noticeable way. viii. Decimation: This is similar to condensation where potentially and important elements are omitted due to speed in discourse of the source information.

ix. Deletion: This is involved with total elimination of parts of a text.

x. Resignation: This form of strategy is used when no translation solution can be found and meaning is inevitably lost.

From the above outlines, Gottlieb (1992) provides a general typology of the various forms of audiovisual translation which remains a cornerstone for subtitling analysis. Condensation is different from paraphrase as it compresses the message while the paraphrase quickly rearranges the sentential structures and also precedes and necessitates paraphrase. Haven looked at the different views of people concerning language, culture and translation, it is discovered that in order to have a clear judgment and better outcome in the study of subtitling as a didactic tool for relating exactness of information and cultural preservation: The Igbo language Mediascape example, the strategy of Gotlieb (1992) and the view of Nida (1964) on equivalence are suitable for the study and as such forms the frameworks of the study.

\section{MethodOLOGY}

In order to carry out the study well, it sets to work with a methodology suitable for it. This study employed the emergent design approach as well as description in its methodology. Its analysis involves the progressive focusing on the data in order to identify and develop themes. So, in order to properly analyse the subtitles gotten from the movie, the researcher follows a three-step procedure. Firstly, by playing and viewing of the Igbo movie. Secondly, re-playing same and determining the strategies used in their subtitling - this is what the researcher did by following the strategy of Gotlieb (1992) and the view of Nida (1964) in order to provide a more comprehensive picture of the study which in turn, reveals a larger variety of translation and subtitling strategies employed by the translators. Thirdly, the researcher played the movie again in order to extract the subtitles so as to enable the researcher to have the correctness of the subtitled expressions of Aka azu di ya in context since the basic unit of a movie in this study is a frame - subtitle. On the significance of the study, the findings of the study shall provide solutions on the following research problems thus, wrong expressions in terms of grammar and context, poor punctuation, capitalization, non alignment with the spoken and the written utterances on the screen which will in turn lead to a better subtitle of Igbo movies in media industries.

\section{DAta PRESEnTATION AND Discussion}

The movie Aka azu di ya is a movie produced by the Realnollywood TV entertainment industry of the Nollywood house. It was exclusively licensed to the Realnollywood movies international AG LTD. It is an Igbo movie subtitled in an English MP4 format with 20 characters. However, the purpose of the study is to look at subtitling as a didactic tool for relating exactness of information and cultural preservation: The Igbo language Mediascape example. Specifically, the objective of the study is to have the correctness of the subtitled expressions of Aka azu di ya in context in order to fit in well in the target audience's language and culture. Categorically, the analysis of the study will strictly be done on the objective of the study as pointed out already.

Discussion of Wrong Expressions in Context

1. TABLE ONE

SHOWING THE USE OF TRANSFER IN 'AKA AZu DI YA'

\begin{tabular}{|l|l|l|}
\hline Igbo language/Asụsụ Igbo & Movie English language subtitle & Correct expressions in context \\
\hline $\begin{array}{l}\text { Nna m gbaghara m, biko gbaghara m, } \\
\text { ọgagh emezi ọzọ }\end{array}$ & Please forgive me it won't happen again & Father please forgive me, it will not happen again \\
\hline $\begin{array}{l}\text { Ma chekwara o, kedụ ihe ị bịara ebe a I } \\
\text { mee? }\end{array}$ & But wait a minute, why are you here & But wait, what have you come here to do? \\
\hline Ọ bụ na ọ bụghị ọsa bụ ihe a & Is that not a squirell...? & Is that not a squirrel...? \\
\hline Kee ka m ga-esi gwa gị? & Why should I tell you? & How can I tell you? \\
\hline ...ihe a abụghị etu ndị nne si eme & ...this is not mothers behave & This is not how mothers behave \\
\hline
\end{tabular}

Based on the table above, transfer strategy was adopted to suit the purpose of the information rendition. Transfer strategy refers to the strategy for translating the source text completely and accurately. It can be clear in the above statements in the table where the message was transferred as the message seems in the source language into the target language. It tries to take the stylistic pattern of the source information while transferring the frames - subtitles. The information above bears witness to this claim. For instance, in the examples of "Nna $m$ gbaghara m, biko gbaghara m, ogaghi emezi ozo" was rendered correctly following transfer method as "Father please forgive me, it will not happen again" Also, "Ma chekwara o, kedu ihe i biara ebe a imee?" for "But wait, what have you come here to do?". Following the tenets of this transfer method, it can be seen that it is in consonance with the theory of Nida. This strategy however retains the original information in another language without meaning lose by allowing the same pattern of 
expression to be retained while maintaining its senses. This is also in conformity with Nida's theory. Since this study adopts the message of Nida's equivalence in form and content because of the target audience, the study sets to achieve it because the two aligns with each other in the form and meaning retention. Categorically, the theory of Nida and strategy of Gotlieb match in the rendering of the movie message in the target language.

2. TABLE TWO

SHOWING THE USE OF PARAPHRASE AND IMITATION IN 'AKA AZu DI YA'

\begin{tabular}{|l|l|l|}
\hline Igbo language/Asụsụ Igbo & Movie English language subtitle & Correct expressions in context \\
\hline Amaara m onye a ọuma & I know him & I know him very well \\
\hline $\begin{array}{l}\text {... hụrụ m ya n'anya, o ga-amasị m ka } \\
\text { mụ na ka di na nwunye }\end{array}$ & $\begin{array}{l}\text { I love him and will like to leave with him } \\
\text { forever }\end{array}$ & $\begin{array}{l}\text { I love him and it will please me to live with him } \\
\text { as husband and wife }\end{array}$ \\
\hline Adaeze, achọrọ m ka ị kpọpụta ndị a kịta & $\begin{array}{l}\text { My princess, I want those people released right } \\
\text { now }\end{array}$ & $\begin{array}{l}\text { Princess, I want those people to be released } \\
\text { right now }\end{array}$ \\
\hline $\begin{array}{l}\text { Ọ bụ Gozie bụ onye kwuru na ọ bụrụ na } \\
\text { mụ akpọpụtaghị ha na alụm di mụ na ya } \\
\text { agaghị enwe isi }\end{array}$ & $\begin{array}{l}\text { It was Gozie who said he wouldn’t marry me if } \\
\text { didn't release them. }\end{array}$ & $\begin{array}{l}\text { It was Gozie who said that the marriage will not } \\
\text { go on if I did not release them. }\end{array}$ \\
\hline $\begin{array}{l}\text { Adaeze ịmụzịkwa anya, ịmazịkwa } \\
\text { omenaala? }\end{array}$ & princes are you sure you're with your senses? & $\begin{array}{l}\text { Princess are you sure you are with your senses, } \\
\text { do you not know the custom? }\end{array}$ \\
\hline
\end{tabular}

\begin{tabular}{|l|l|l|}
\hline $\begin{array}{l}\text { Nna m gbaghara m, biko gbaghara m, } \\
\text { ogaghị emezi ọzọ }\end{array}$ & Please forgive me it won’t happen again & $\begin{array}{l}\text { Father please forgive me, it will not happen } \\
\text { again }\end{array}$ \\
\hline $\begin{array}{l}\text { Ọ kakwara gị mma na ị hapụrụ agwa } \\
\text { ojọ̣ gị a ma biwe ndụ ọụụ̣ }\end{array}$ & $\begin{array}{l}\text { I advise you turn a new leaf today before its } \\
\text { late }\end{array}$ & $\begin{array}{l}\text { It is better for you to leave this your bad } \\
\text { behaviour and turn to a good way of life }\end{array}$ \\
\hline $\begin{array}{l}\text {..nwa gi nwoke emetala ihe igwe na ọha } \\
\text { obodo ga-eji chụpụ gị n'obodo }\end{array}$ & $\begin{array}{l}\text { Now, he's done what will makethe community } \\
\text { to banish you }\end{array}$ & $\begin{array}{l}\text {...your son has committed what the king and the } \\
\text { community will banish you from the land }\end{array}$ \\
\hline $\begin{array}{l}\text { Ọ bụ Chike ka ị na-ajụ, ajụjụ adịghịị ya. } \\
\text { Kee nke q ma ọ ga-ekwu? }\end{array}$ & $\begin{array}{l}\text { No, don’t ask him. the question is not for him. } \\
\text { what can he say? }\end{array}$ & $\begin{array}{l}\text { Is it Chike that you are asking, question is not } \\
\text { for him. What does he know to say? }\end{array}$ \\
\hline $\begin{array}{l}\text { Jonathan nwa m, ahụ ahụna gị ahụ. Ọ } \\
\text { bụrụ na ọ bụ ihe gbasara ego, hapụrụ m } \\
\text { ego, ezuru m ka emee na ya ... }\end{array}$ & $\begin{array}{l}\text { Don’t panic Jonathan.I will take care of } \\
\text { anything that involves money.I'm equal to the } \\
\text { task... }\end{array}$ & $\begin{array}{l}\text { Jonathan my son, do not worry. If it is issue of } \\
\text { money, I will take care of it... }\end{array}$ \\
\hline
\end{tabular}

Based on the table above, it can be discovered that in order for the researcher to render a correct subtitle in context, the dynamic equivalence of Nida (1964) is adopted as well as the strategies of Gotlieb (1992). The idea of Nida's equivalence is to maintain sameness in the meaning of the source information with its equivalence in the target language even when there is language difference thus, interlingual subtitle. The translator followed it in order to have a replica of the original information in another language such that there will be no meaning lose. In the use of equivalence, the translator tried as much as possible to use it in style and content based on the reason that an audiovisual study which is actually focused on the use of terms based on context. It does not actually look at the sameness based on having just correct utterances of the source information in the subtitled form rather; having a clear transfer based on the situation that prompted up the utterances of the actor or the source speaker and why such utterances are made hence, its mannerism. For instance, in the table above an expression goes thus: Jonathan nwa m, ahu ahuna gi ahu. O buru na $O$ bu ihe gbasara ego, hapuru $m$ ego, ezuru $m$ ka emee na ya... Herein, 'ahu ahuna gi postulates the fidgeting nature of Jonathan when he was asked to render help while in another context, there would be meaning loss. However, 'ahu ahuna gi ' is replaced with 'do not worry' thus, 'Jonathan my son do not worry. If it is issue of money, I can take care of it... So, the employed strategies are paraphrase and imitation. Paraphrase as used in the table states that the translators who undergo subtitle exercise resorts to its use in a situation where same syntactic way in the ST cannot be reconstructed in the target language so that the original meaning will be retained. The translator equally used imitation which is one of the strategies. This is involved in the subtitle because; it maintains the same forms, typically with names of people and places unaltered. However, since the focus is on expressions in context in this segment, it tries to capture all the rudiments of the utterances of the source speaker in order to suit the intended message set for the target audience to have.

3. TABLE THREE

SHOWING THE USE OF CONDENSATION IN 'AKA AZu Di YA'

\begin{tabular}{|c|c|c|}
\hline Igbo language/Asxsx Igbo & English Language & Correct expressions in context \\
\hline $\begin{array}{l}\ldots \text { a sịị } \mathrm{m} \text { ka } \mathrm{m} \text { kelee unu maka etu unu } \\
\text { si zụo } \mathrm{m} \text { wee zuruo } \mathrm{m} \text { etu a } \mathrm{m} \text { ha... }\end{array}$ & $\begin{array}{l}\text {...I thank you and my father for everything } \\
\text { and for traing me till now... }\end{array}$ & $\begin{array}{l}\text { I want to thank you for training me up to this } \\
\text { stage }\end{array}$ \\
\hline $\begin{array}{l}\text { Amara m na o nweghi ka ị ga-agwa nne } \\
m \text { na I bu nwa nwa ya n'afọ ọ chụpụ gị }\end{array}$ & $\begin{array}{l}\text {...and I know my mother can eject you if you } \\
\text { told her this }\end{array}$ & $\begin{array}{l}\text {...I know that there is no how my mother will } \\
\text { chase you away if you tell her that you are } \\
\text { carrying her grandchild. }\end{array}$ \\
\hline Nneọma gbaghara m, amaghị m ụma. & $\begin{array}{l}\text { Please forgive me Nneọma. It was not } \\
\text { intentionally }\end{array}$ & $\begin{array}{l}\text { Nneọma please forgive me, it was not } \\
\text { intentional }\end{array}$ \\
\hline $\begin{array}{l}\text {...nwatakịị unu gụrụ gụnye na osu } \\
\text { n’enweghi ihe ọbụla o mere unu }\end{array}$ & $\begin{array}{l}\text { The person you all term an outcast without any } \\
\text { offenses }\end{array}$ & $\begin{array}{l}\text { A child you termed an outcast without any form } \\
\text { of offense }\end{array}$ \\
\hline
\end{tabular}

Based on the above table, the translator adopted the principle of condensation in order to have the same effect of the Igbo language information in the target language English. Condensation is the subtitling strategy that results to 
shortening of the source information in a noticeable way.

4. TABLE FOUR

SHOWING THE USE OF EXPANSION AND TRANSFER IN 'AKA AZu Di YA'

\begin{tabular}{|l|l|l|}
\hline Igbo language/Asụsụ Igbo & Movie English language subtitle & Correct expressions in context \\
\hline $\begin{array}{l}\text {..ụdị ego e ji ebido ahịa building } \\
\text { materials abụghị ihe mmadụ ji ọnụ } \\
\text { akọ...em, mmadụ adịghị abụ onye a } \\
\text { kwọ n’azụ ọ kwọrọ mmadụ ibe ya. }\end{array}$ & $\begin{array}{l}\text { materials business is so enormous and byou } \\
\text { know a beggar does not feed a beggar }\end{array}$ & $\begin{array}{l}\text { The kind of capital for starting a building material } \\
\text { benefactor }\end{array}$ \\
\hline
\end{tabular}

This rendition in the above table as done in the two strategies, from the Gotliebs strategy used for the study are transfer and expansion. Transfer refers to the strategy of translating the source text completely and accurately while expansion is used for the source information when it requires explication due to gaps in the involved cultures. However, the original information was actually transferred following the stylistic effect of the source language while the expansion was used to explain, thus making the information of the original to be explicit to the target audience. This is to say that more explication to the original message was used, and examples can be seen from the above table.

\section{CONCLUDing REMARKS}

In conclusion, it can be seen from the study that culture, language and translation seriously work together in the sense that the help of one brings about the beauty of the other. This study focused on 'subtitling as a didactic tool for relating exactness of information and cultural preservation: The Igbo language Mediascape example' by making sure that the exact expression of the source movie is rendered well in the target language based on the context it was used - this is what the study did. However, from the study, it is discovered that culture plays vital role in the lives of the target audience as it determines how they will react to the translated information especially when it involves a literary translation. It is also discovered that language is important in any translation exercise as what happens in a particular language is so much dependent on the culture and belief system of the receptor language. More so, it is discovered that in literary translations, culture is not separated from translation because, whatever the translator will render into the target language will solely be dependent on the culture that will receive it or else, the translation will not be functional in the target culture that received it. On the part of the correctness of the source information expressions, it is discovered that by the strategy of Gotlieb and Nida's translation equivalence, the researcher was able to correctly transfer the right messages aright and in context in which they are used. More so, by doing this, it is discovered that the research objective is achieved thereby attaining the signification of the study.

\section{REFERENCES}

[1] Bartoll, E. (2004). Parameters for the classification of subtitles. In Pilar Orero (ed.), Topics in Audiovisual Translation 53-60. Amsterdam/Philadelphia: John Benjamins Publishing Company.

[2] Bassnett, S. (2008). Translation studies. USA: Routledge.

[3] Dwyer, T. (2017). Fansub dreaming on ViKi. The Translator, 18(2), 217-243. doi:10.1080/13556509.2012.10799509.

[4] Fawcett, P. (1996). Translating film. In Geoffrey, T. H. (ed.), On Translating French literature and film, 65-88. Amsterdam: Rodopi.

[5] Gelavizh, A., Saman, S., Elenaz, J., Arezoo, S. \& Siamak, S. D. (2012). Language, Translation, and Culture. 2012 International Conference on Language, Medias and Culture IPEDR, vol.33

[6] Giwa, E. T. (2014). Nollywood: A case study of the rising Nigerian film industry - content \& production, MA Thesis, Graduate school Southern Illinois University Carbondale, 1-51.

[7] Gottlieb, H. (1992). Subtitling-a new university discipline. In Dollerup, C. \& Loddegaard, A. (Eds.), Teaching translation and interpreting: training talent and experience: papers from the first language international conference, Elsinore, Denmark, 1991161-170.

[8] Graedler, A. L. (2000). Cultural shock. Retrieved February 10, 2021 from http://www.lif.uio.no/iba/nettkurs/translation/grammar/top7culture.html.

[9] Harvey, M. (2000). A beginner's course in legal translation: the case of culture bound terms. Accessed on April 3, 2020. Retrieved from http://www.tradulex.org/Actes2000/harvey.pdf.

[10] Hatim, B. \& I. Mason (1990). The Translator as Communicator. London and New York: Routledge.

[11] Ivarsson, J. (1992). Subtitling for the media: A handbook of an art. Stockholm: Transedit.

[12] Jiraphatralikhit, I., Klinpoon, S. \& Kamehameha, S. (2005). An analysis of strategies in translation of the movie subtitle: Behind the painting. Research Gate 1, 54-71. Retrieved October 2020 from http://aut.researchgateway.ac.nz/handle/10292/87ohtml.

[13] Larson, L. M. (1984). Meaning-based translation: A guide to cross-language equivalence. University Press of America: Lanham.

[14] Liu, C. (2014). The multimodal approach in audiovisual translation. Target, 28(2), 222-236.

[15] Munday, J. (2001). Introducing translatiom studies: Theories and application. Oxon: Routledge.

[16] Newmark, P. (1991). About translation. Multilingual Matters.74, pp184. Retrieved February 10,2021 from https://benjamins.com/online/target/articles/target.5.2.11sch.

[17] Newmark, P. (1988). Approaches to translation. Hertfordshire: Prentice Hall.

[18] Nida, E. A. (1964). Toward a science of translation. Leiden: Brill. 
[19] Nord, C. (1997). Translation as a purposeful activity: Functionalist approaches explained. Manchester: St. Jerome

[20] Nwike, C. C. (2021). An intersemiotic translation of Nkape anya ukwu. Journal of Language Teaching and Research, 12(2), pp. 245-251. DOI: http://dx.doi.org/10.17507/jltr.1202.04.

[21] O'Connell, E. (2007). Choices and Constraints in Screen Translation. In L. Bowker et. al.(eds.). Unity in Diversity? Current Trends in Translation Studies 65-75. Beijing: Foreign Language Teaching and Research Press.

[22] Parson, T. (1949). Essay in sociological theory, pure and applied. The Free Press of Glencoe: New York.

[23] Sarcevic, S. (1985). Translation of Culture-Bound Terms in Laws. Multilingua 4 (3), 127-133.

[24] Schaffner, C. (2007). Politics in translation. In P. Kuhiwezak, and K. Littau (Eds.). A companion to translation studies 134 -147. UK: Multilingual Matters Ltd.

[25] Shuttleworth, M. \& Cowie, M. (2007). Dictionary of Translation Studies. Manchester: St. Jerome Publishing.

[26] Szarkowska, A., \& Wasylczyk, P. (2018). Five things you wanted to know about audiovisual translation research but were afraid to ask. Journal of Audiovisual Translation, 1(1), 8-25.

[27] Vermeer, H. J. (1998). Starting To unask what translatology is about. Target, 10(1). pp. 41-68. Doi: https://doi.org/10.1075/target. 10.1.03ver.

[28] Weston, M. (1991). An English reader's guide to the French legal system. Oxford: Berg

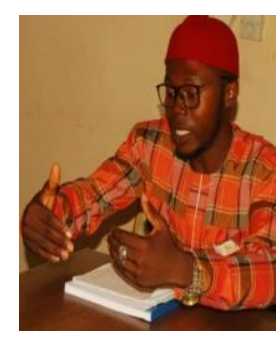

Christopher C. Nwike is a native of Onitsha, Onitsha North Local Government Area of Anambra State. He was born in Ogidi, Anambra State on the $3^{\text {rd }}$ of May. Christopher C. Nwike is a trained translator. Mr. Nwike belongs to the Association of Translation Studies in Nigeria. He also obtained an academic Merit Award in Honour of Aknu-ibiam As the Best Graduating Student Who Produced the Best Long Easy in Igbo Language in Linguistics Department, University of Nigeria, Nsukka. His areas of specialisation are Translation, Interpreting, Semantics and Studies in Igbo language.

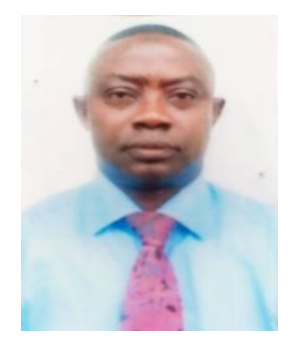

Olaide Abduwaheed Oladimeji was born in Ibadan, Nigeria in 1969. He received his $\mathrm{PhD}$ degree in Linguistics from the University of Ibadan. He is a lecturer 1 in the department of Linguistics and Languages, Federal University, Oye-Ekiti, Nigeria. His research interests include Phonology and Syntax of African Languages. Dr. Oladimeji is a member of Linguistics Association of Nigeria (LAN).

Harriet Chinyere Obiora bagged BA in Linguistics from Ebonyi State University and MA in Linguistics from the University of Nigeria, Nsukka. Harriet specialises in Discourse Analysis and Pragmatic. She has published in Journal of language Teaching and Research,Vol 12,No.3,pp.494-500,May 2021. Mrs obiora is a member of the Linguistics Association of Nigeria. She is also a PhD student in the Department of linguistics, igbo and other Nigerian languages, University of Nigeria Nsukka. 